\title{
A Unified Competitive Palestinian Strategy
}

\author{
Samir A. Awad ${ }^{1, *}$ \\ ${ }^{1}$ Birzeit University, Birzeit, West Bank, Israel \\ *Correspondence: Birzeit University, Birzeit, West Bank, Israel. E-mail: sawad@birzeit.edu
}

Received: May 12, 2017

Accepted: June 26, 2017 Online Published: July 27, 2017

doi:10.5430/sass.v4n2p46

URL: https://doi.org/10.5430/sass.v4n2p46

\begin{abstract}
Palestinians need a strategy that will lift them out of their seemingly unending dilemma of prolonged Israeli settler-colonial occupation. Palestinian strategy needs to be re-positioned, to be part of a published strategic vision for a lasting solution that needs a national consensus on the requirements.

The Palestinian struggle to achieve a viable independent state can be attained by engaging in a contest of credibility generating a long term sustainable advantage responding to the opportunities and threats, to achieve our objectives through capturing international political signals; or as Edward Said described it "Capturing the Imagination of the world".

The purpose of strategy is to gain some form of advantage; to maintain or protect assets or interests. Strategy is about gaining or maintaining an advantage or denying an advantage to the Israeli Occupation.

To set a strategy, one usually employs past experience tactics whereby future probabilities, gains and losses are approximated in a given situation (game theory). A strategy is not routinely changeable or is quickly reversible. Nevertheless, a strategy must not stand still in the face major international events. On the contrary, a solid strategy must be capable of responding to changing events in a manner whereby tactical threats could be turned into gains or opportunities. It is also necessary that a strategy ought to be, when formulated, based upon the strengths whist remaining mindful of weaknesses in order for it to deal with arising threats or challenges.

For over two decades, since the signing of the Oslo Accords between the Palestinian Liberation Organization and Israel, the Israeli military occupation, land confiscation and destruction, expansion of settlements, denial of Palestinian right to self-determination and control over natural resources remain in place.

Israel continues with its settler-colonial project undeterred by the Palestinian resistance or the condemnation of most countries in the world. That has undermined the so-called "Peace process" and its ultimate objective of a two-state solution, leaving the Palestinians with a prospect of prolonged occupation, which leaves them helpless and hopeless.
\end{abstract}

Keywords: strategy, resistance, settler-colonial occupation, contest of credibility, maintaining advantage, Fatah and Hamas, Palestine and Israel, two-state solution

\section{Introduction}

Politicians and commentators argue for the need of a clear and unified strategy for ending Israeli occupation and building a viable Palestinian state.(Note 1) In the current situation of compound political and geographical division, between Gaza Strip and the West Bank, and between Fatah and Hamas, the largest two Palestinian parties, the objective of independence seems to be remote.

At the same time, Israel continues with its settler-colonial project undeterred by the Palestinian resistance or the condemnation of most countries in the world. That has undermined the so-called "Peace process" and its ultimate objective of a two-state solution, leaving the Palestinians with a prospect of prolonged occupation, which leaves them helpless and hopeless.

This calls for a strategy that lifts Palestinians out of their seemingly unending dilemma; Palestinian strategy needs to be re-positioned, to be part of a published strategic vision for a lasting solution that needs a national consensus on the requirements. 
The Palestinian struggle to achieve a viable independent state can be attained by engaging in a contest of credibility generating a long term sustainable advantage responding to the opportunities and threats, to achieve our objectives through capturing international political signals, or as Edward Said described it "Capturing the Imagination of the world". (Note 2)

\section{What We Mean by Strategy?}

Strategy as a concept is used to denote long term planning(Note 3) undertaken by decision-makers known for their extraordinary vision, who have preconceived ideas and answers to questions that might arise in the future, reflecting a high degree of insight depth, and awareness of how the world of politics operates. (Note 4)

The purpose of strategy then is to gain some form of advantage; to maintain or protect assets or interests; or to effect a desired change of one sort or another(Note 5)

Strategy is about gaining or maintaining an advantage or denying an advantage to the Israeli Occupation. It should be a clear, simple vision of where you want to end. Therefore, strategy refers to basic directional decision as it consists of the important actions necessary to realize these directions. (Note 6) Strategy is the bridge between policy or high order goals on the one hand and tactics or concrete actions on the other. (Note 7)

To set a strategy, one usually employs past experience tactics whereby future probabilities, gains and losses are approximated in a given situation (game theory). A strategy is not routinely changeable or is quickly reversible. Nevertheless, a strategy must not stand still in the face major international events. On the contrary, a solid strategy must be capable of responding to changing events(Note 8) in a manner whereby tactical threats could be turned into gains or opportunities. It is also necessary that a strategy ought to be, when formulated, based upon the strengths whist remaining mindful of weaknesses in order for it to deal with arising threats or challenges.

Taking the present Palestinian situation, for instance, one finds it almost deadlocked against many layers of complexities. For over two decades, since the signing of the Oslo Accords between the Palestinian Liberation Organization and Israel(Note 9), the military occupation, land confiscation and destruction, expansion of settlements, (Note 10) denial of Palestinian right to self-determination and control over natural resources remain in place. (Note 11) This condition was further exacerbated by internal factors; mainly the painful "political" division between Gaza and the West Bank despite the formation of a government of national unity, Israel encouraged the political division by adopting a "separation policy" to eliminate the travel between the two areas(Note 12). These amalgams of negative factors constitute substantial stumbling blocks for Palestinians and constrict their maneuverability and reduce the effectiveness of Palestinian strategy for liberation. However, according the famous Palestinian Poet, Mahmoud Darwish, Palestinians must overcome their difficulties not abandon hope, surrender or deviate from strategic goals principally, the right to return and live in their free state.

Along its progression, the conflict fundamentally altered meanings, images, and identities of the parties involved. (Ernest,1983) Framing the conflict as the Israeli Palestinian conflict is in itself the outcome of a profound transformation in both camps. (Note 14)

The subsequent question is what could Palestinians do to make their strategy sustainable and implementable? The answer is confronting occupation and settlers along direct engagement frontiers including the East Jerusalem. Such are the lines of agitation where foreign and Israeli solidarity could be attracted and gather momentum to display before the eyes of the world community the immorality and illegitimacy of occupation. Furthermore, Palestinians could resort to invasion of the space where Palestinians narrate their case. This thinking cannot be belittled or underestimated, because it would certainly show the moral upper hand of people under occupation. Not realizing, or deliberately setting such an option aside would be a real cause for concern.

The current state of stagnation in which the Palestinian case is caught up in can be ended through a gradual process of fragmenting the immense volume of challenges by referring each element in the crisis to the party who possesses the keys to resolving it. It is crucial to begin the process with differentiating between local and external factors. This must not be seen as an aggressive peace campaign but a peaceful defensive strategy to re-position the Palestinian strategy on the right track.

\section{4 Phases of Strategy}

Palestinians adopted several strategies along the way to achieve their main goals of independence and self determination and the return of refugees. All the while their focus was on solidifying the camp of allies and 
progressing towards ending the Israeli occupation of Palestine. These strategies went through four major phases : Armed struggle, popular resistance (intifada), negotiations, and finally a strategy of BDS, Popular resistance, and accession to international organizations.

1 Armed struggle (select elite): 1965- 1985

Edward Said argues in Culture and Imperialism that imperialism and resistance exist in a state of relentless systemic dialectic: there can be no colonialism without resistance. (Edward, 1993)

With the outbreak of the modern Palestinian revolution on January $1^{\text {st }} 1965$, a phase of arm struggle ensued with clear objectives to liberate the whole of Palestine from Zionists colonialism. It was stated in the Palestinian Liberation Organization charter in article 9 that the armed struggle is a strategy and not a tactic and shall be continued until victory. (Note 16)

Palestinians who regard themselves as the "rightful indigenous inheritors of all the Arab communities that have settled in Palestine since time immemorial" went on with their resistance against the Israeli colonial authorities. (Note 17)

Armed struggle defined the nature of the Palestinian resistance, which went along side with that particular phase of anti-colonial liberation movements in the world. That struggle was invigorated with the "Karama" battle on 1968, in which "Fedaeyeen" guerrilla fighters clashed with and defeated the Israeli invasion to Jordan with the great help of the Jordanian Army. Following that, "FATEH" managed to enter and then lead the PLO in which case the PLO adopted armed struggle as a strategy and became the sole legitimate representative of the Palestinian people. This phase went on for two decades with ups and downs that were accompanying the road which was outside Palestine.

Indeed, the Palestinian people were engaged in irregular decolonization efforts carrying out guerrilla attacks against the Israeli occupation authority, which peaked during the war on Lebanon in 1982.

2 Intifada (people's struggle): 1987- 1993

This new phase of peoples struggle had to start with the retreating of the armed struggle at the time, (Yezid, 1986) and was based inside the West Bank and Gaza Strip, occupied by Israel in 1967 war. The Intifada was a statement of rejection to that occupation and a call for liberation of Palestine.

Intifada started as a sustained collective movement of resistance with commitment to both anti-colonial struggle and social justice. (Note 19) The Intifada, besides being a moment of transformation in the political conflict, "triggered some of the most intriguing work in the field of social history," both inside and outside Palestine. (Ilan, 1999) The Intifada as a movement introduced far-reaching change to social and political life in Palestine, with consequences exceeding the influence of any other political movement. The Intifada was able to monopolize the national political discourse in Palestine, and to provide a basis for mobilizing public will and collective action. (Note 20)

During the Intifada Palestinians, then united and empowered, were able to boycott, nullify, and then disable the institutions of occupation and replace them with a new set of national institutions, headed by the underground PLO-affiliated Unified National Leadership of the Intifada (UNLU) which acted as a national government. (Don, 1990) UNLU introduced a new political agenda based on self-determination and independence and directed the struggle against the Israeli occupation, while preparing the grounds for a declaration of independence. People's committees, simultaneously, were organizing day-by-day life in every Palestinian neighborhood, in a striking decentralized structure, quite unlike the inefficient, authoritarian structure of the PLO. (Joost, 1991) The Intifada leadership gave great importance to the formation of people's organizations and committees, which were conceived as voluntary associations for the mobilization of collective power, and a "quasi-democratic" structure for political and social life in Palestine. (Note 21) Palestinians had a role in the determination of their daily affairs particularly in the first two years of the Intifada through a web of decentralized "peoples [neighborhood] committees" and sectoral associations. This was in sharp contrast to the old institutions of authoritarian, patriarchal structure. (Emile, 1988) The Palestinians had developed a vibrant civil society during the Intifada, with over nine hundred popular and voluntary associations, human rights organizations, as well as powerful trade unions and women's movements. These organizations fought, with limited success, to defend the freedom of expression, freedom of association, political pluralism, and decentralization of authority. Therefore, for the local leadership, activists, and NGOs, the prospects of the establishment of the long-awaited "democratic and secular Palestine" did not seem so unrealistic. (Note 22) This worked parallel to the centralized militant resistance of Shabab [youth], which was controlled and directed through organizational channels, leaflets, and daily orders. (Khalil, 1997) 
3 Negotiations (Failed Strategy): $1995 \sim 2015$

The Palestinian National Council (PNC) adopted the two-state solution in 1988, after the first Intifada broke out in the West Bank and Gaza. It consequently accepted UN Security Council Resolutions 242 and 338 and later recognized Israel. After the PLO dropped the claim to these territories (in Israel proper), the issue of territorial compromise (vaguely defined) was becoming part of mainstream politics on the Palestinian side as well as on the Israeli side. Both sides, of course, differed on what it means in reality or where the borders should be drawn. The change in the Palestinian position was drastic, with the most far reaching consequences in Palestinian history. (Glen, 1999)

Mounting Israeli oppression in the West Bank and Gaza coupled with increased land confiscation and a wide range of collective punishments that the Occupation employed triggered a number of clashes and mass confrontations in the 1980s. The expansion of Israeli settlement on Palestinian land exacerbated the situation and added a sense of urgency to the need to confront and end the Israeli occupation. The widely held feeling of being left (by the Arab countries and the weakened and isolated PLO) to confront the Israelis alone forced the Palestinians under occupation to take charge of their fate and organize anew the resistance movement. These developments and mass confrontations were the precursor to the Intifada which broke out in December 1987. (Note 23)

Following the Oslo accords and the establishment of the Palestinian Authority, the two parties saw in negotiation the road ahead for the peace talks. Primarily it was supposed to last from 1994 to 1999 when an independent Palestinian state would be established, a promise that was not fulfilled by the Israelis. The Palestinians switched their strategy to negotiations while Israel continued with firm steps its old and consistent strategy of land confiscations and settlements activities. This was the biggest factor of the disappointment feeling spread among Palestinians which was then turned into the second intifada 2000-2007, which failed to have a unique type of confrontation, it was not a military or armed intifada neither a public resistance intifada, and then did not reach to any fruitful outcomes. Instead of having a temporary peace process as an intermediate step towards independence, the Palestinians found themselves drowned in a continuous negotiation process moving in a closed circle. Almost all Palestinian parties are against the idea of negotiation only for negotiation, and since negotiations stopped in 2015, the Palestinian leadership is asking for a timeframe for any future negotiations and a clear reference which is assumed to be the UN resolutions related to the Palestinian case. Almost all Palestinians now are convinced that the previous era of negotiations was a big fail. (Note 24)

\section{BDS \& International Support: 2015}

The current road ahead is comprised of three distinct strategies: the first is the boycott, Divestment and sanctions (BDS) as a tool of resistance to the Israeli occupation and the second is an attempt to achieve representation in many international organizations, and the third is popular resistance so that the occupation's measures are challenged constantly in the occupied territory.

The BDS was launched on 2005 and is having big steps and achievement which encourage the Palestinian people and their supporters to see it as a potential successful strategy, The BDS is facing many obstacles put by Israel and its supporters and by the Zionist movement in many countries, and was even described to be anti-Semitic organization, these steps could not stop the BDS but will make it take longer time to achieve its goals. (Note 25)

Popular resistance is available as an option. Societies under occupation exercise the right to resist their occupier. Popular resistance is an important strategy to pursue for any people under occupation, and it is consistent with international law so it cannot be labeled as terrorism. (Note 26)

Increasing Palestinian effort has been put into achieving further representation in international organizations, such as UNESCO, ICC and Geneva conventions the Rome Statute. (Note 27) Meanwhile the Palestinian leadership is in pursuit of a permanent membership in the $\mathrm{UN}$ and other international organizations.

This "three faceted strategy" represents the continuation of the strategic track aiming at decolonization and ending the Israeli Occupation.

It is worth noting that up till now and despite adopting numerous strategies, no strategy has achieved its goals of liberation and independence and the struggle continues.

\section{Breaking the Dilemma}

Once the moral base for resistance (popular resistance) is put into place a close look into the present situation would reveal that the trap in which the Palestinian issue is stuck manifestly complicated by: 
- Pressure exercised by international powers.

- Palestinian factional and party rifts.

- Contradictory or obscure Palestinian parties' aims and visions.

- Fragility and unreliability of influential international powers.

\section{Adopting an All-Encompassing National Strategy}

The internal Palestinian "Political" division must be ended. This, however, need not necessarily mean reconciliation between Hamas and Fatah; rather, it is a means to a common end. A daily popular resistance activity against Israeli occupation is the ideal tool with which Palestinians can make a case for themselves on the international arena. (Note 28) Indeed, popular resistance would reflect a consolidated national standpoint that could be geared to face the future and embedded challenges. Only then can one employ international political signals, analyze standpoints and thus determine who the ally is.

The following parts of the article unveils the enormous nature of the internal crisis (a multi layered deadlock) then tackle each component of the crisis with a view to resolving them separately from external crises through the adoption of existing initiatives for peace or by developing a new one. Henceforth, Palestinians will have a breathing space for tackling the significant issues as indicated below.

First: the identity or the very being of the Palestinian political system in contrast with the nature political systems as provided for by political theories. Any given modern political system is actually an institutional expression of self-determination. The political system is, therefore, the space in which citizens enjoy individual freedoms, such as, free expression and the right to self-realization as well as self-interest. What could be said about the Palestinian political system? Is it democratic in the sense that it tolerates the others? Does it respect individual rights? Does it accept citizens' participation in policy making or in political arbitration? The answer to these questions needs a comprehensively critical view which is lacking at present.

Second: the nature of Palestinian political factions. Are they political parties or resistance and national liberation movements? There is certainly a disturbing absence of clarity of vision amongst the relevant factions that negatively affected the nature of aims and attitudes. What is also clear is that narrow factional interests surpass the national interest and the institutional dimension of the political system. The Palestinian political system ought to be, like happens in all multiparty systems, where parties are able to reach consensus on vital national interests and policy issues. Moreover, where there might be conflict on procedural matters all parties to the conflict must resort to resolving their grievances in the appropriate court of law.

That is to say, in the final analysis Palestinians convert movements into competitive political parties prior to trying to be democratic.

Third: the real lack of proximity amongst political faction makes it virtually impossible for Palestinians to generate a clear support at the international stage. In addition, that amounts to a convenient pretext for Israel to "scream wolf", no real Palestinian peace partner. Amongst the several various peace initiatives was that by the Arabs and adopted by the League of Arab States at the Beirut summit in 2002, (Note 29) which guaranteed Arab and European support on the one hand, and a conditional recognition of Israel, on the other. That initiative was supported by the states of the Non-Alignment Movement, as well as by the European Union, but the rift between Fatah and Hamas was perceived responsible for the failure of the peace talks.

Fourth: the Palestinian public continues to refrain from active participation in the political process and stays aloof of effective or constructive critique of the current state of affairs. Therefore political apathy has been a contributory factor in deepening factional political chaos. Although political apathy could not be excusable, some might justify it by referring to the recurrence of past disappointments.

\section{An Action Plan on the International Stage}

In such a gloomy situation it is impossible for Palestinians to benefit from, or manipulate political moves on the international stage for their benefit. Yet, successive Palestinian governments have got to better use international political instruments and not to resign themselves to failure or to negative attitudes because that would never accomplish the desired breakthroughs. Palestinians might intelligently choose to benefit from reconciling the variant programs of the major political actors. Fatah, for example, is adamantly committed to peaceful negotiations, whilst 
Hamas is unswervingly committed to armed resistance. In politics this is known as the two levels game. According to this theory, the President of the Palestinian Authority can effectively strengthen his negotiating stance with Israel by making - a legitimate - reference to an aggressively objectionable parliament. Democracy would definitely tip off the balance of power in favor of Palestine against Israel.

Once again, we have to remind ourselves with the thinking of Edward Said who, urged the Palestinians not to underestimate the word "NO" because no is a natural and a logical answer that responds most appropriately to propositions denying Palestinians of their rights, which the world recognizes all too well.

What is required of the Palestinians now is not a speedy return to the negotiations table, rather a critical evaluation to all the work that has been done over the years with the purpose of drawing useful conclusion. In addition, the authorities have to resort to the people and politicians in Palestine as well as in other Arab countries to redefine the nature of relations internally and externally, especially, after the so called "Arab spring" and the rise of fundamentalist and terrorist movements. (Note 30)

The dream of independence can become true only through a simultaneous process of resistance and negotiations; political initiatives; making concerted efforts to block unilateral solutions and allay international pressure and by ending the blockade that has been suffocating Palestine. All that should be carried out by political means rather than by military means.

\section{The Future Components of a Palestinian Strategy}

Palestinians have several and varying sources of strength that ought not to be neglected when preparing a future strategy. The first of those sources of strength is the very fact that Palestinian people are still on their land despite all efforts to uproot them by the occupation forces. This is most certainly a critical factor that remained invariably in favor of Palestinian citizens. By the same token it is most agonizing for Israeli governments and entire polity of the occupation. The Zionist vision for the Israeli state was essentially based upon emptying Palestine of its inhabitants and replacing them with Jewish settlers to realize the Jewish democratic state. However, that vision has been blinded by the steadfastness of Palestinians on their land. Arab citizens inside Israel constitute about one fifth of the population of Israel, and the number of Arabs in historic Palestine almost equals the number of Jewish colonists. That is an impressive victory which can be counted for the Palestinian demographic battle.

The second source of strength is the fact that there is a Palestinian Authority on the territory of Palestine for the first time in history. This, too, is a significant source of strength even from the view point of those who might differ politically with the PNA. For, it being there is more than symbolic. It is a governing system with political, economic, education and health institutions that secure continuity for the people. The Palestinian Authority is not a factor to be taken lightly in the thinking about the strengths upon which a strategy is built, and a preliminary step towards statehood.

A third point of strength for the Palestinian strategy is the continuous struggle by Palestinians which, over the years generated global support for the cause, publicly, politically and legally. There could never be a contrast between the Palestinians who demand self-determination and those Israelis who persist with occupying land not theirs and build Jewish settlements on it.

The fourth point is the supportive stance by the Palestinian civil society for the Palestinian Authority towards establishing an independent state of Palestine via abroad spectrum of relations with sympathetic counterparts in many places around the world. The economic and academic boycott movements are but two of the many manifestations of international moral and material support. Palestinian civil society serves as a pressure tool for the development of democratic institutions and is a virtual watchdog for justice and good governance.

Another very important point is the fact that Palestinians are holding still on to the land of their ancestors despite persisting Israeli violations of their human rights and freedoms. Today's Palestinians say gone are the days when it was possible to transfer or force people out of their homes; present day Palestinians are well aware that nowhere in the world is an acceptable alternative to home in Palestine.

Finally, one cannot forget the role of the media for, it plays a central role in communicating Palestine's narrative to the world community. Here the Palestinian Authority is expected to assume the greater share of responsibility for formulating the narrative and for voicing it where it ought to make the desired echoes. Here, the Hamas-Fatah rift should be overcome to ensure that Palestinian media does not appear to send inconsistent messages to the world, or to the local population as was the case lately when Palestinians got caught up in the false dialogue about the negotiations reaching a dead end and abut a breakthrough in the national reconciliation. The popular media focused declarations by observers and politicians about considering last or alternative options, and so on and so forth. 
Palestinians are affected by all sorts of difficulties, such as, the refugees, political and physical being, absence of state, persisting settlement expansion, destruction and confiscation of agricultural land, and the decrease of landscapes for demographic growth.

There should be a serious study, inclusive of all the Palestinian mosaic - urgently needed- with the view to revaluating the past couple of decades to mend what has been broken by mistaken judgments, the disappointingly damaging rift between Gaza and the West Bank. There has got to be a union of vision and agreement on commonalities to maximize the returns of what has been accomplished on the ground. This is the way a head, rather than demolishing everything that has been painstakingly built in order to restart building all over again.

\section{Public Diplomacy and the Palestinian Division}

In harmony with the popular Arab uprising in the region, Palestinians flooded out to the streets calling upon their political leaders to end the division and restore national unity by reiterating "the people want ending the division". It was then clear that Palestinians that the paramount aim of Palestinians had been high jacked by the futility in the debate about the rift between Gaza and the West Bank despite there being a government of national unity. The present political state of affairs necessitate the reunion of the geography of Palestine and subsequently uniting the political well of leaders and decision makers. Palestinians in Gaza are besieged by Israeli military, poverty, inadequate healthcare or education, the economy is neither growing nor productive; it is dependent on smuggling goods in and out of that part of Palestine. Gazans are dependent on Israeli manufactured products and services, such as, food items medicine, gas and oil, etc. Here, in such an environment where the international community gave a lot of support, public diplomacy might step in to help alleviate the suffering of the people of Gaza.

We cannot go on without making real effort to reverse this painful condition, naively putting so much faith in the good intentions of the main players at all levels. Furthermore, we cannot go on distorting our case and message at a time when parliaments in Latin America and Europe are voting for the recognition of an Independent Palestinian state. The successes we scored on the Arab and world stages. All that is needed to be done could not be realized without a clear strategy consisting of tactics capable of responding to arising eventualities and that decisively resonate with the core demands of the Palestinians.

Lately Fatah celebrated its $51^{\text {th }}$ anniversary; an event that, more than at any time, reminds the movement of the enormous responsibility that lies upon it towards the Palestinians. The occasion impresses upon Fatah to seek the means for developing a strategy that lifts Palestinians out of the seemingly a non-ending dilemma. The movement must work to accomplish the vision for which it was originally designed and is apparent in its literature.

\section{References}

Don Peretz, (1990). Intifada: The Palestinian Uprising. Boulder: Westview Press.

Edward W. Said (1993). Culture and Imperialism. New York: Vintage Books.

Emile Sahliyeh, (1988). In Search Of Leadership: West Bank Politics Since 1967. Washington, D. C.: The Brookings Institution.

Ernest Gellner (1983). Nations and Nationalism. Ithaca: Cornell University Press.

Glen Robinson (1999) Building a Palestinian State: The Incomplete Revolution. Bloomington and Indianapolis, Indiana University Press.

Ilan Pappé (ed.) (1999). The Israel/Palestine Question. London: Rutledge.

Joost Hiltermann (1991). Behind the Intifada, Labor and Women's Movements In The Occupied Territories. Princeton: Princeton University Press.

Khalil Shikakiet.al., (1997). The Palestinian Civic Experience and the Transformation to Democracy in Palestine. Nablus: Center for Palestine Research and Studies.

Yezid Sayigh (1986). Palestinian Armed Struggle: Means and Ends. Journal of Palestine Studies, 16(1), 95-112. https://doi.org/10.2307/2537024 


\section{Notes}

Note 1. Khalil Shikaki, Changing the Status Quo: What directions for Palestinians?,The Palestinian Center for Policy and Survey Research (PSR), p2.

Note 2. Edward Said, The only alternative. Al-Ahram Weekly On-line. 1 - 7 March 2001. Issue No.523.

Note 3. Harry R. Yarger, STRATEGIC THEORY FOR THE 21st CENTURY, p1,31,35

Note 4. Caspar F. van den Berg, Strategic Planning for Political Parties:A Practical Tool, p18

Note 5. John Williams, What is 'Strategic Communications'?, OffspinMedia, www.offspinmedia.co.uk

Note 6. George Steiner, Strategic Planning, in Fred Nickols, Strategy Definitions \& Meanings, p.3

Note 7. Fred Nickols, Strategy Definitions \& Meanings p.7

Note 8. Harry R. Yarger, STRATEGIC THEORY FOR THE 21st CENTURY, p35

Note 9. signed in Washington, D.C., in 1993.

Note 10. Permanent Observer of the State of Palestine to the United Nations

Note 11. WEINBERGER, Peter Ezra. Co-opting the PLO: A critical reconstruction of the Oslo Accords, 1993-1995. Lexington Books, 2007.

Note 12. OCHA monthly overview, Occupied Palestinian Territories, Aug 2016.

Note 14. Ahmed Al-Deik, Mujtama' al-Intifadah, [Arabic: The Intifadah Society] (Beirut: Dar al-Adab, 1993) p.52-56

Note 16. PLO website, PLO charter. This article was annulled in 1998.

Note 17. Sari Nusseibeh, and Mark Heller, No Trumpets, No Drums: Two-State Settlement of the Israeli-Palestinian Conflict, (London : I. B. Tauris, 1991) p.32

Note 19. Glen Robinson, Building a Palestinian State: The Incomplete Revolution. pp. x-xi

Note 20. Ibid. pp. 90-91

Note 21. Hiltermann, Behind the Intifada pp.214-215

Note 22. HananAshrawi, This Side of Peace, pp. 10-11

Note 23. Ahmed Al-Deik, Mujtama' al-Intifadah, p.52

Note 24. Khalil Shikaki, Changing the Status Quo: What directions for Palestinians? Final Report, Palestinian Center for Policy and Survey Research, P1,2. May 2016.

Note 25. Mahmoud Alnawajaa, BDS Movement Achievements and Challenges. AlQuds University. Master's thesis, p80

Note 26. Sufian Abu Zaida. Peaceful Popular Resistance: Is it an Option? In Khalil Shikaki, Changing the Status Quo: What directions for Palestinians? Final Report, Palestinian Center for Policy and Survey Research, P1,2. May 2016.

Note 27. International Criminal Court website, https://www.icc-cpi.int/palestine.

Note 28. Sam Bahour, Asynchronous and Inseparable Struggles for Rights and a Political End-Game. Changing the Status Quo: What directions for Palestinians?. P9

Note 29. Arab affairs Journal, Vol 110, Summer 2002. P257

Note 30. European Policy Centre,The Arab Spring, the changing Mediterranean, and the EU: tools as a substitute for strategy?

Note 31. Established by PLO on July 1994 following the OSLO Agreement. 